\title{
Java v Open Source GIS - Geotools, Geoserver, uDig
}

\author{
Ing. Jan Ježek \\ Department of Mapping and Cartography \\ Faculty of Civil Engineering, CTU in Prague \\ E-mail: jan.jezek@fsv.cvut.cz
}

Key words: Java, GIS, Open Source, uDig, Geotools, Geoserver

\section{Úvod}

Open Source GIS pokrývá většinu oblastí pro správu geografických dat. Open Source GIS produkty lze rozdělit na dvě hlavní skupiny, a to na produkty napsané v jazyce $\mathrm{C}(\mathrm{C}++)$ a na produkty v jazyce JAVA.

\section{V jazyce $\mathbf{C}$}

V tomto jazyce jsou to především UMN Mapserver, GRASS, Thuban a knihovny GDAL/OGR, PROJ4, GEOS.

\section{V jazyce JAVA}

V tomto jazyce jsou to GeoServer, uDig, Jump a knihovny GeoTools, JTS.

Základním stavebním kamenem každého Open Source GIS je možnost připojení k databázi PostGIS/PostgreSQL, které umožñují obě skupiny.

\section{Projekty v jazyce C}

Obecně platí, že projekty v jazyce $\mathrm{C}$ jsou mnohem vyzrálejší, a to především díky delšímu časového období jejich vývoje. Základem těchto projektů jsou softwarové knihovny znázorněné na následujícím obrázku. Knihovny lze stáhnout například jako produkt FWTools. (http:// fwtools.maptools.org/).

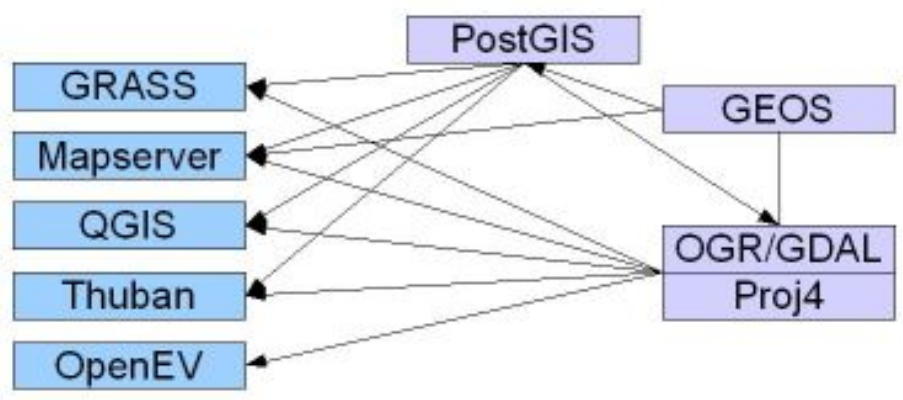

FWTools 


\section{Sdílené knihovny}

\section{PROJ4}

Knihovna pro práci s kartografickými zobrazeními v jazyce C. Hlavním autorem obou knihoven je Frank Warmerdam.

web site http://remotesensing.org/proj/

\section{GEOS}

GEOS je "Geometry Engine, Open Source“. Jedná se o implementaci jednoduchých prostorových prvků podle OGC specifikace "Simple Features for SQL" a metod pro topologii. Knihovna je vytvořená v $\mathrm{C}++$.

web Site: http://geos.refractions.net/

\section{Projekty v jazyce JAVA}

Projekty v jazyce JAVA probíhají vývojem a momentálně proto nemůžou ještě př́liš konkurovat těm v jazyce $\mathrm{C}$, a to především kvůli problémům při práci z obsáhlejšími daty. Přesto se zde vyvíjí komplexní řešení všech částí GIS produktů. Existuje několik nezávislých projektů (OpenMap), ale také komplexní řešení na bázi knihoven a jejich implementací do desktop i do server GIS produktů. Schéma vztahů mezi knihovnami a GIS produkty je patrné z následujícího obrázku:

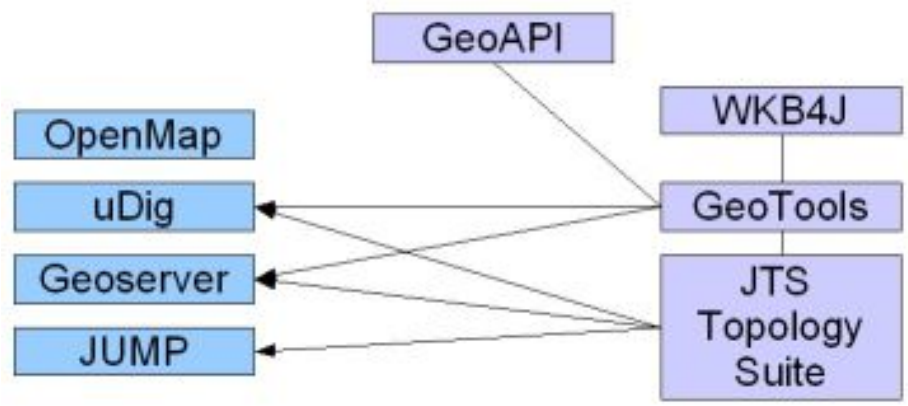

\section{Sdílené knihovny}

\section{GeoAPI}

GeoAPI je skupinou JAVA rozhraní vycházejících z OGC specifikací. GeoAPI definuje návrh objektů a jejich metod pro základní operace z geografickými daty. Cílem GeoAPI je vytvoření standardního systému JAVA rozhraní tak, aby bylo možné propojovat jakékoliv nově vytvořené knihovny s těmi stávajícími.

Web Site: http://geoapi.sourceforge.net/

\section{JTS Topology Suite}


JTS Topology suite je základní knihovna používaná prakticky ve všech GIS produktech v jazyce JAVA. Tato knihovna představuje obdobu knihovny GEOS v jazyce C tzn. Představuje implementaci OpenGIS "Simple Features Specification". Knihovna obsahuje topologické funkce jako Contains(), Intersects(), Touches() a Coesses().

Web Site: http://www.jump-project.org/

\section{GeoTools}

Geoltools představuje Open Source JAVA GIS toolkit pro vývoj GIS produktů z velkým důrazem na OGC specifikace. Cílem projektu je vývoj JAVA objektů potřebných pro finální GIS produkty (jde o jistou obdobu ARCObjects od firmy ESRI). Velký důraz je kladen především na modularitu celého systému, tak aby uživatel mohl využívat jen ty části, které skutečně potřebuje.

Web Site: http://docs.codehaus.org/display/GEOTOOLS/Home

\section{Vybrané GIS produkty}

\section{GeoServer}

Geoserver je implementací Web Feature Server specification OpenGIS konsorcia založené na jazyce JAVA (J2EE). Aplikace je postavena na knihovně Geotools, což umožňuje oddělenou správu základní logiky. Z technického hlediska se jedná o webovou aplikaci založenou na JSP a servletech fungující pod některým z aplikačních serverů (např. Tomcat). Základní př́́klad aplikace můžete vidět např. na adrese http://b9701.fsv.cvut.cz:7080/geoserver/.

Oproti nejrozšiřenější obdobné aplikaci UMN Mapserver vyniká především jednodušší instalací i obsluhou. V současnosti umožňuje serverovat tyto datové formáty:

\section{- Oracle Spatial}

- ArcSDE

- PostGIS

- ESRI Shape Files

Tato data jsou zpřístupněna jako služby WFS, WMS nebo WFS-T (Služba umožňující i editaci dat). Zatím bohužel ještě nebyla implementována podpora serverování rastrových dat, avšak její zakomponování je otázkou přištích měsíců. Zajímavostí je plánovaná podpora služby WCS (Web Coverage Service ), která umožňuje serverovat multidimenzionální rastrová data např. rastrová data spolu s informací o nadmořské výšce pixelu (digitální model terénu).

Dalším výhodou oproti kunkurenčním produktům je možnost serverovat data ve formátu KML, a tak je zobrazovat v aplikaci Google Earth viz obr.

\section{uDig}

Produkt uDig (User-friendly Desktop Internet GIS) představuje desktop GIS produkt. Spolu s aplikacemi Geserver, GeoTools i PostGIS je i uDig vyvíjen firmou Refractions Research. Je postaven na knihovně GeoTools a na technologii Eclipse Rich Client Platform. V Současnosti uDig poskytuje tuto funkcionalitu: 


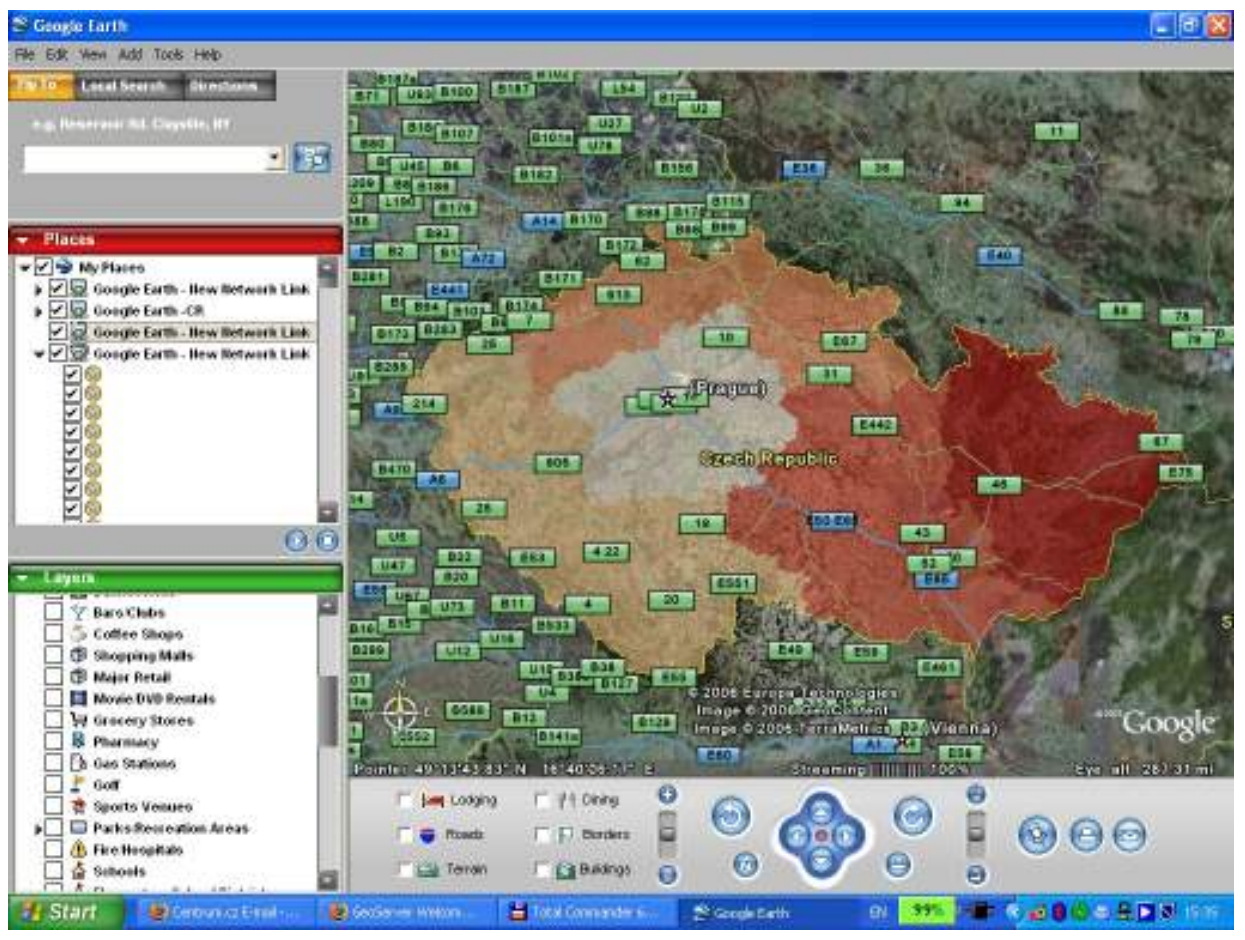

Geoserver + Google Earth

- WFS client read/write umožňuje jak prohlížení tak editaci dat poskytovaných prostřednictvím služby WFS a WFS-T.

- WMS client umožňuje prohlížení dat zprostředkovyných pomocí WMS služby

- Podporuje Styled Layer Descriptor (SLD), umožňuje barevnou tematizaci grafických podkladů (přidělení barvy prvku dle hodnoty jeho atributu)

- Podpora tiskového výstupu

- Podpora standardních GIS formátů

- podpora práce se souřadnicovými systémy

- Podpora připojení databází- PostGIS, OracleSpatial, ArcSDE, and MySQL.

- uDig je nezávislý na platformě Windows, OS/X, and Linux.

\section{Závěr}

Rozššření jazyku Java se výrazně odráží i ve vývoji Open Source GIS. Popsaná skupina produktů naznačuje budoucí vývoj v této oblasti. Kladem uvedeného řešení je především veliká modularita a podpora OGC specifikací. Během př́štích let bude zajímavé sledovat vývoj těchto produktů, které jsou možnou open source alternativou ke komerčním produktů firmy ESRI. PostGIS jako alternativa ArcSDE, geoserver jako alternativa ARCIMS, uDig jako alternativa ArcMap, GeoTools jako alterantiva ArcObjects. Stále se však jedná o produkty ve 


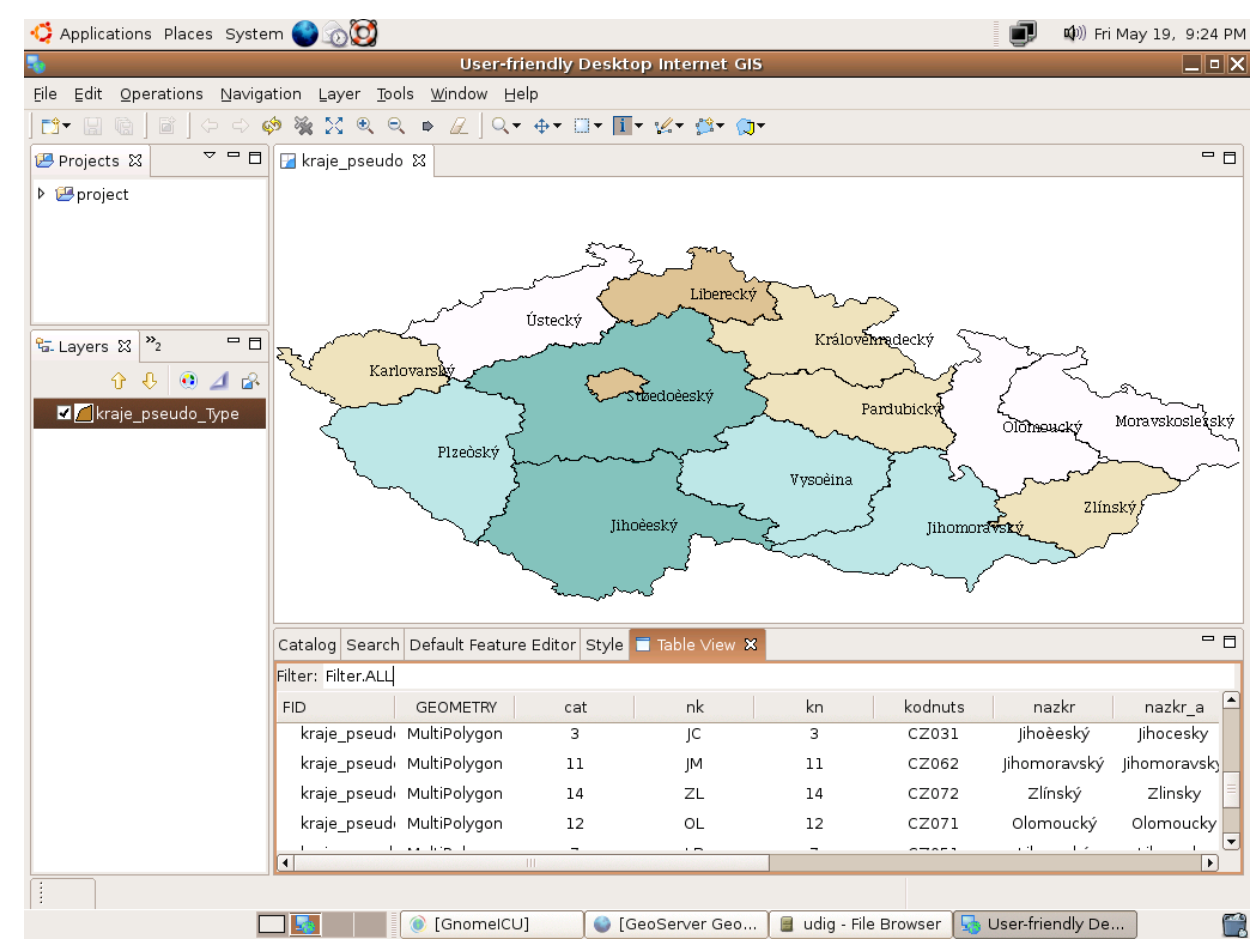

$\mathrm{uDig}$

vývoji, které se potýkají s řadou problémů, především co se týče rychlosti a práce s obsáhlými daty.

\section{Reference}

1. Open Geospatial Consortium,Inc ${ }^{1}$ - Open Geospatial Consortium,Inc. Home Page [200605-10]

2. Refractions Research ${ }^{2}$ - Refractions Research Home Page [2006-05-10]

3. FWTools ${ }^{3}$ - FWTools Home Page [2006-05-10]

\footnotetext{
${ }^{1}$ http://www.opengeospatial.org/

${ }^{2}$ http://www.refractions.net/

${ }^{3}$ http://fwtools . maptools .org/
} 